\title{
Principles of Culturally Relevant Education in an Ethnomathematical Perspective
}

\author{
Milton Rosa ${ }^{1}$ \\ Universidade Federal de Ouro Preto (UFOP), Instituto de Ciências Exatas e Biológicas, \\ Departamento de Educação Matemática, Ouro Preto, MG, Brasil \\ Daniel Clark Orey ${ }^{2}$ (D)
Universidade Federal de Ouro Preto (UFOP), Instituto de Ciências Exatas e Biológicas,
Departamento de Educação Matemática, Ouro Preto, MG, Brasil
}

\begin{abstract}
The implementation of culturally relevant education assists in the development of student intellectual, social, and political learning by using their cultural referents to develop mathematical knowledge. It uses prior experiences of students to make learning more relevant and effective in order to strengthen their connectedness with schooling. Culturally relevant schools contextualize teaching and instructional practices while maintaining academic rigor. In these schools, educators, teachers, school leaders, and staff members are able to recognize and build upon the strengths of the students by applying instructional strategies that are culturally relevant. Culturally relevant leadership is grounded in the conviction that students are able to excel in their academic endeavor. In this context, it is necessary to enable the implementation of culturally relevant pedagogy into the curricula, designed to fit together school culture with students' background in order to help them to conceptualize knowledge. Ethnomathematics and culturally relevant pedagogy-based approaches to mathematics curriculum are intended to make mathematical content more meaningful and relevant to students. Hence, the main objective of this article is to discuss the importance of principles of culturally relevant education in accordance to an ethnomathematics perspective.
\end{abstract}

Keywords: Culturally Relevant Education; Culturally Relevant Pedagogy; Ethnomathematics.

\section{Princípios da Educação Culturalmente Relevante em uma Perspectiva Etnomatemática}

\section{Resumo}

A implantação da educação culturalmente relevante auxilia no desenvolvimento do aprendizado intelectual, social e político dos alunos por meio da utilização de referências culturais para desencadear o conhecimento matemático. Esse tipo de educação utiliza a experiências prévias de alunos para tornar o aprendizado relevante e efetivo, pois visa reforçar a sua conexão com as atividades escolares. As escolas culturalmente relevantes contextualizam a instrução e as práticas escolares enquanto mantém o rigor acadêmico. Nessas escolas, os líderes escolares, os professores e os funcionários são capazes de reconhecer e construir com base nos pontos fortes dos alunos por meio

\section{Submetido em: 14/09/2019 Aceito em: 30/11/2019 Publicado em: 01/01/2020}

${ }^{1}$ Doutor(a) em Educação, Liderança Educacional, pela California State University, Sacramento. Professor do Programa de Pós-Graduação em Educação Matemática da Universidade Federal de Ouro Preto. Endereço para correspondência: Rua Pref. José de Castro, no. 32, Apto. 101, Cabeças, 35400-000 Ouro Preto Minas Gerais. E-mail: milrosa@ hotmail.com.

${ }^{2}$ Doutor em Educação, Currículo e Instrução e Educação Multicultural pela The University of New Mexico. Professor do Programa de Pós-Graduação em Educação Matemática da Universidade de Ouro Preto. Endereço para correspondência: Rua Pref. José de Castro, no. 32, Apto. 101, Cabeças, 35400-000 Ouro Preto Minas Gerais. E-mail: oreydc@ gmail.com. 
da aplicação de estratégias instrucionais que são culturalmente relevantes. A liderança culturalmente relevante está enraizada na convicção de que os alunos são capazes de se destacarem em projetos acadêmicos. Existe a necessidade de facilitar a implementação da pedagogia culturalmente relevante nos currículos escolares, que é projetada para embeber a cultura escolar nos backgrounds culturais dos alunos, auxiliando-os a conceituar o conhecimento. As abordagens da etnomatemática e da pedagogia culturalmente relevante no currículo matemático visam tornar os conteúdos matemáticos relevantes para os alunos. Assim, o objetivo desse artigo teórico é discutir os princípios da educação culturalmente relevante de acordo com a perspectiva etnomatemática.

Palavras-chave: Educação Culturalmente Relevante; Pedagogia Culturalmente Relevante; Etnomatemática.

\section{Principios de la Educación Culturalmente Relevante en una Perspectiva Etnomatemática}

\section{Resumen}

La implementación de una educación culturalmente relevante ayuda al desarrollo del aprendizaje intelectual, social y político de los estudiantes mediante el uso de referencias culturales para activar el conocimiento matemático. Este tipo de educación utiliza las experiencias previas de los estudiantes para hacer que el aprendizaje sea relevante y efectivo, ya que tiene como objetivo fortalecer su conexión con las actividades escolares. Las escuelas culturalmente relevantes contextualizan la instrucción y la práctica escolar mientras mantienen el rigor académico. En estas escuelas, los líderes escolares, los maestros y el personal pueden reconocer y desarrollar las fortalezas de los estudiantes mediante la aplicación de estrategias de instrucción que son culturalmente relevantes. El liderazgo culturalmente relevante se basa en la convicción de que los estudiantes pueden sobresalir en proyectos académicos. Es necesario facilitar la implementación de una pedagogía culturalmente relevante en los planes de estudio escolares, que están diseñados para sumergir la cultura escolar en los antecedentes culturales de los estudiantes, ayudándoles a conceptualizar el conocimiento. Los enfoques de las etnomatemáticas y de la pedagogía culturalmente relevante en el plan de estudios matemáticos tienen como objetivo hacer que los contenidos matemáticos sean relevantes para los estudiantes. Por lo tanto, el objetivo de este artículo teórico es discutir los principios de la educación culturalmente relevante desde la perspectiva etnomatemática.

Palabras clave: Educación Culturalmente Relevante; Pedagogía Culturalmente Relevante; Etnomatemáticas.

\section{Introduction}

Demographic shifts in many countries have led to increasing numbers of culturally, linguistically, socioeconomically diverse students in their educational systems. For example, the resulting requirement that schools report disaggregated data have brought increased attention to achievement gaps that have persisted for years between minority students and their mainstream peers (GÁNDARA, MAXWELL-JOLLY; RUMBERGER, 2008). According to a wide range of educational indicators including evaluations, retention rates, and school dropout rates; it is necessary to highlight that significant inequities continue to exist for students from distinct cultural groups in relation to their scores on standardized tests; dropout and graduation rates, and enrollment in higher education (ROSA, 2010). 
One possible explanation for these gaps may be that disparities in achievement that stem in part from a lack of fit between traditional schools, in which practices are derived almost exclusively from Western cultures, and that from the local/home culture of students (LADSON-BILLINGS, 1995). Students whose cultural backgrounds are rooted in western ways of thinking possess an innate educational advantage as compared to students from distinct sociocultural contexts and other cultural backgrounds. In this regard; these students are required to learn through cultural ways of thinking and practices other than their own in which students from dominate cultures do not contend with or have to do (ROSA, 2010).

This sociocultural mismatch is often a result of widely divergent worldviews about fundamental concepts such as human nature, political, economic, natural and educational environments, and social relations. Related to this argument, an educational system rooted in the dominant culture is inherently biased (D'AMBROSIO, 1990). Therefore, if the set of cultural beliefs developed by the members of distinct cultural groups is considered to be right, then the values of the members of other cultures may be treated as less valid, as well students from these groups may be perceived as culturally deficient3 (KLINGNER, ARTILES; BARLETTA, 2006).

The cultural deficiency model is often used to explain differences in achievement that exist among students from diverse and often very different social, racial, and ethnic groups. Any gaps in student achievement are based on environmental factors, lifestyles, and values developed by the members of minority groups, which form the basis for cultural deprivation, and highlights the so called inferiority of members of a given cultural group. The absence of a specific cultural background leads many students to a sense of alienation not only from their school environment but from their traditional support system as well (ATKINSON, MORTEN; SUE, 1993).

It is important to argue that "it is not clear of what culture (...) families and their children can be deprived since no group can be dispossessed of its own culture. It appears, therefore, that the term becomes a euphemism for saying that working-class and ethnic groups have cultures which are at least dissonant with, if not inferior to, the 'mainstream' culture of the society at large" (KEDDIE, 1973, p. 8). If sociologists focus their attention on the supposed deficiencies of the students, in terms of cultural deprivation, then, they fail to notice the shortcomings in school instructional and teaching strategies. In this context, the concept of cultural deprivation suggests that the dominant culture considers that members of distinct cultural groups, such as the ones from lower social classes, have inferior norms, values, skills, and knowledge, which prevent them from achieving in education. Thus,

\footnotetext{
${ }^{3}$ The definition of cultural deficit or culturally deficient is found in Passow's Education in the book entitled Education in Depressed Areas that was written in 1963. According to the National Commission on Excellence in Education (NCEE, 1983), the concept of cultural deficit approach also reappeared in the 1980s with the definition of students at risk.
} 
inferior language skills and the fact that working-class parents do not value education are largely to blame for working class underachievement (TULKIN, 1972).

The deficit model functions as if students do not have a sense of their own culture. This is most striking as often cultural deprivation is used to impose conservative white middle-class values in an attempt to link poor school performance, as well as low self-esteem and motivation, to problems with learners who come from homes, families, traditions, and cultural values (TRUEBA; BARTOLOMÉ, 1997) that do not match those of the dominant group. These deficient cultural values include present versus future time orientation, immediate instead of deferred gratification, an emphasis on cooperation other than competition, and the placing of less value on education and upward mobility (ROSA, 2010) as seen by members of the dominant culture.

It is important to note that this model labels internal social structure of families and students as deficient. Such perceived deficiency is seen to be the result of large, disorganized, female-headed families; where Spanish or other non-standard English is spoken at home; and patriarchal or matriarchal family structures (TRUEBA; BARTOLOMÉ, 1997).

Furthermore, since parents of minority students fail to assimilate and embrace the educational values of the dominant culture and continue to transmit or socialize their children with values that inhibit educational mobility, they are to blame if low educational attainment continues into succeeding generations. In the cultural deficit model, students coming from minority cultures are described as failing to attain the same levels of socioeconomic and academic status obtained by the majority culture due to the so called disadvantages and failures of the minority experience itself (ROSA, 2010).

Most criticism concerning cultural deficit models in education are related to the promotion of cultural stereotyping that contributes to unproductive efforts to show minority or low-income students' home or school settings as the source of lower achievement. If researchers, school leaders, teachers, and educators assume a univocal view of culture as a universally valid ideal roughly equivalent to the condition of being civilized, then it is hard to determine how the label of culturally deficient adds to the common-sense notion of uneducated students and how cultural deficiency could be a cause of school failure (KRETOVICS; NUSSEL, 1994).

In practice, the deficit model more often or not, is applied to schools and students of color and minority students by school leaders and teachers who are professionally trained in educational programs that utilize an individualistic and culturally deficit explanation of low educational attainment of minority students. The cultural deficit model remains the hidden theory of choice that many school leaders and teachers apply in their professional meetings and settings when the topic of minority educational inequality is discussed (ROSA, 2010). 
In this educational environment, many school leaders, educators, and teachers struggle to connect with diverse student populations whose cultural backgrounds are distinctly different from their own. It is necessary that school leaders, teachers, and staff members embrace the relevance of culture as a means of helping all students reach high standards in a culturally relevant educational environment. In other words, by adopting a culturally relevant education framework, school leaders may be able to address issues of educational inequity and confront institutional bias and discrimination (NORTON, 2005).

Educators may be able to avoid some of the consequences of the cultural deficit model such as higher rates of indiscipline and suspension among minority students (ROSA, 2010). However, in order to reach this goal, student culture, native language, and cultural dialects must be valued and used as assets in their learning process rather than deficits, which is one of the main objectives of the ethnomathematics as a program.

Over the last three decades, theories of culturally relevant pedagogy and ethnomathematics were developed in order to ease these sociocultural concerns. This kind of pedagogy is considered as an oppositional pedagogy in which collective empowerment is its focus center. In other words, the overall goal of culturally relevant pedagogy is to empower students through learning activities that helps them to develop literacy, numeracy, technological, social, and political skills in order to be active participants in a democratic society (LADSON-BILLINGS, 1995).

We also emphasize here that culturally relevant pedagogy studies the cultural congruence between students' cultural backgrounds, communities, and schools. Along with this, ethnomathematics is considered as the cultural anthropology of mathematics and mathematical education lying at the confluence of mathematics and cultural anthropology (ROSA; OREY, 2007). In relation to the pedagogical work in schools, mathematical curricular activities must be relevant to the students' cultural backgrounds.

In other words, the "views of pedagogy within the literature on ethnomathematics are compatible with work on culturally relevant pedagogy" (HART, 2003, P. 42) because it examines the cultural congruence between students' community and school. This means that cultural congruence indicates teachers' respect for the social, cultural, and linguistic backgrounds of their students. However, it is necessary that both school leaders and teachers be supported and encouraged to acquire knowledge of and respect for the diverse cultural traditions, languages, and mathematical knowledge found in their community and students, so they are able to implement the principle of cultural congruence in their schools and classrooms (D'AMBROSIO, 1990).

Since mathematics usually tends to be presented as a set of objective and universal facts and rules, mathematics is often viewed as culture free and not considered a socially and culturally 
constructed discipline (LEE, 2003). However, to change this perception, it is necessary that school leaders and teachers understand what counts as knowledge in mathematics as well as how knowledge may be related to norms and values of diverse cultures. If school leaders, teachers, and educators deal with integrating diverse cultures in the schools and classrooms, then they need a conceptual framework to make coherent decisions regarding to the curricular activities concerning the development of mathematics curriculum.

According to this context, the aim of this article is to show that there is a need to examine the embeddedness of mathematics in cultures by drawing pedagogical actions from an ethnomathematical perspective that takes on the cultural nature of knowledge production into the mathematics curriculum. Our argumentation is that culturally relevant education, culturally relevant schools, culturally relevant leadership, and culturally relevant pedagogies are considered ethnomathematical approaches to the development of the mathematics curriculum since they intend to make school mathematics relevant and meaningful to the students regarding the promotion of overall quality of their educational experiences.

\section{Culturally Relevant Education}

Educational systems must be relevant to the emotional, psychological, and educational needs of all students (DARLING-HAMMOND, 1997). Since an established link exists between student cognitive performance and their cultural environmental context, the development and implementation of a culturally relevant educational program is one of the best approaches we can make to ameliorate minority student achievement gaps (ROSA, 2010). For example, Maddahian (2004) has gathered evidence regarding the existence of Culturally Relevant Educational Programs (CREP) in a large school district in California in which the random sample included 16 elementary, 12 middle, and 3 high schools that were selected for observation and data collection.

This conceptual framework is considered as a comprehensive model dealing with all aspects of instruction and education. During the conduction of this study, Maddahian (2004) trained a team of fifteen data collectors to observe teachers and classroom environments in order to document evidence of culturally relevant instruction through detailed field notes; and in direct classroom observation. The results of this study showed that there was almost no evidence of multicultural content in instructional delivery as well a sense of community presence were exceedingly rare in the schools in the study.

Finally, it was concluded that the implementation of CREP is a complex and challenging endeavor faced by many California schools. It becomes essential for school leaders to learn to respect and value all the cultural backgrounds of their student population and to apply instructional strategies 
whereby all its students may benefit from their experiences and learning styles. In order to build a school cultural climate in which all students learn and achieve, school leaders and teachers need to be supported and encouraged to develop sociocultural awareness to be able to understand, appreciate and integrate the use student needs and perspectives (MADDAHIAN, 2004).

Culturally Relevant Education is defined as an educational theory "that honors, respects, and values diversity in both theory and in practice and where teaching and learning are made relevant and meaningful to students of various cultures" (KLOTZ, 2006, p. 11). It is strengthened by incorporating a wider diversity of social, cognitive, and cultural experiences into a successful teaching and learning environment for all students by instilling the ethics of care, respect, and responsibility by the professionals who serve minority students such as school leaders, teachers, and staff (ROSA, 2010).

In this perspective, according to Beauboeuf-Lafontant (1999), culturally relevant schools create and implement educational environments that facilitate processes of reflection, inquiry, and mutual support around issues of cultural difference for educators. The reflections that take place in these environments encourage and allow educators to understand, respect, often to encouraged individual differences as well as to strive for high educational standards and levels of achievement.

\section{Culturally Relevant Schools}

In culturally relevant schools, all students receive instruction through pedagogical actions that engage them intellectually by taking into account the pedagogical decisions affecting them the most. This is especially important for those who have been traditionally marginalized by the school system (LADSON-BILLINGS, 1995).

The "benefits of culturally competent schools are numerous and include preventing academic failure, reducing dropout rates, and engaging students and their families in the school community" (KLOTZ, 2006, p. 11). These schools are grounded in the belief that minority students are able to excel academically when their culture, language, heritage, and experiences are valued and used to facilitate their learning (GAY, 2000).

In culturally relevant schools, the teaching and learning processes are relevant and meaningful to all students, specifically to students from various cultures. The "goals for culturally competent schools are to establish settings where all students are made to feel welcome; are engaged in learning; and are included in the full range of activities, curricula, and services" (KLOTZ, 2006, p. 11).

In this perspective, Burns, Keyes and Kusimo (2005) and Rosa (2010) affirm that all students, regardless of ethnicity or socioeconomic status, have an opportunity to learn to high standards and are encouraged to learn by acquiring knowledge in multi-dimensional pedagogical activities based on context, interests, experiences, knowledge, and skills that they bring daily to their classrooms. 
eISSN: 2526-9062

Revista de Educação Matemática, São Paulo, SP, v. 17, 2020, p. 1-24 - e020001 


\section{Culturally Relevant Leadership}

The demands on school leaders in the public school system have escalated in response to changing demographics and pressures on student achievement. School cultural, linguistic and economic diversity requires school leaders to create communities that support learning and improve the achievement of all its members. School leaders are called on to act on their commitment to culturally relevant pedagogy in the service of just humane, and equitable school communities by collaborating with families and other community stakeholders (FARMER; HIGHAM, 2007).

Culturally relevant school leaders recognize that culture means far more than recognizing racial and ethnic differences. They must be willing to be engaged in learning in order to demonstrate an understanding of various cultures and be able to respond effectively to issues of culture and diversity in order to facilitate students' learning (ROSA, 2010). They have to respond to diverse community interests and needs and mobilize community resources in order to demonstrate and promote ethical standards of democracy, equity, diversity, and excellence and promote communication among diverse groups.

Culturally relevant school leaders "create systems that support democratic education" (DAVIS, 2002, p. 5). However, it is necessary to develop a school-wide commitment that is dedicated to cultural relevancy and reciprocity in order to guide school leaders' work to influence their own practice. An emphasis on the need for a culturally relevant leadership reflects on the influence culture has on the learning process. In so doing, in addition to leadership skills, school leaders need to acquire cultural intelligence in which it is necessary to learn about how other cultures define and exert leadership in order to gain and maintain cultural proficiency (WIBBEKE, 2009).

For example, a study conducted by Agbo (2002) focused specifically upon how the cultural roles of administrators of Native-American students translate into strategies that allow them to learn more effectively. This study reviewed the Mohawk Education Curriculum Development Project, which was developed though collaboration between administrators, public school teachers, and members of the school community to elaborate a culturally relevant standards-based curriculum that addressed problems of high dropout rates and underachievement of Mohawk students.

Culturally relevant school leaders lead best by focusing attention and action on difficult questions while enduring problems faced by their schools. In so doing, they need to be culturally proficient in order to deal with the realities of oppression and to work with other stakeholders in order to eliminate oppression from their schools (DAVIS, 2002). However, they need to find their own voice, develop their own political understanding and advocacy to their leadership practices. This 
means that the development of culturally relevant leaders "is premised upon egalitarian principles that transcend individual cultural norms" (FARMER; HIGHAM, 2007, p. 2).

The core principles of culturally relevant leadership are sensitive to cultural nuances in communication processes, deliberate and sequential processes, appreciation of one's own cultural biases, and cultural responsiveness in education. Thus, an inclusive learning environment in which an appreciation of diversity, in culturally relevant leadership models, school leaders' values and leadership styles shapes the school climate for learning and achievement and addresses cultural issues (GAY, 2000). This means that culturally relevant school leaders must be capable of motivating and energizing an increasingly heterogeneous student body in their schools in order to avoid cultural dissonance $^{4}$ (YBARRA, 2001).

The concept of cultural dissonance is related to a disconnection between student cultural background and the corresponding thought processes of students in diverse classroom learning environments. In many educational systems, minority students often experience a sense of cultural dissonance, making them vulnerable to educational disadvantages. Since culturally relevant leadership styles are rooted in the belief that students can learn and that every student has intrinsic cultural value, culturally relevant school leaders need to challenge students to their fullest potential because high expectations in schools are the norm (FULLAN, 2001).

In this perspective, they must find ways to avoid the consequences of cultural dissonance, which is a tendency of students' abandonment of their inherent cultural values to adopt those of the school culture in order to achieve academic success (YBARRA, 2001). However, providing culturally relevant materials cannot completely eliminate cultural dissonance, school leaders need to constantly monitor and review aspects of both the formal and informal curricula. In so doing, learning contexts must also allow for differences in the values, knowledge, skills, and learning styles that students bring to the classroom (Rosa, 2010).

Culturally relevant leadership is considered a relational and ethical process that occurs when leaders lead the school community to work together to accomplish positive change. This suggests that if given support, all stakeholders will work toward resolving differences among the members of the school community, finding a common direction, and building a shared vision to improve schools (Rosa, 2010). In this regard, leadership is culturally relevant and inclusive when members of the school community understand, value, and actively engage diversity in views, approaches, styles, and aspects of individuality such as culture that add multiple perspectives to a group's activity (KOMIVES, LUCAS; MCMAHON, 2007).

${ }^{4}$ Cultural dissonance may be considered as a sense of discord, disharmony, and conflict experienced by students in the midst of change in their cultural environment (Allan, 2002). 
Because school leaders attend to values and personal beliefs as well as intellectual percepts in matters of culturally relevant leadership practices, culturally relevant school leaders are also considered moral leaders. It is necessary to emphasize the concepts of moral and transformational leadership because the relationship between the leader and the staff must be genuine. In other words, moral leaders' behaviors must be consistent and aligned with the needs and values of their followers (BURNS, KEYES; KUSIMO, 2005).

Other characteristics of moral leaders include those of assuming responsibility for actions and commitments made to their followers, keeping promises made by personally leading the change, and understanding that alternatives exist and having a willingness to switch direction if needed. It is necessary that school leaders refine their educational programs in order to meet the pedagogical necessities of their students. For example, English Language Learner (ELL) student achievement occurs when school leaders maintain literacy and matheracy of all students as high priorities, motivating all teachers to participate in the improvement of the pedagogy of the schools (ROSA, 2010).

In a culturally relevant leadership, school leaders provide supervision in order to move their faculty forward to best meet the needs of their minority students' population by implementing best practices such as culturally relevant pedagogy. Thus, culturally relevant school leaders work with the school community to develop and provide adequate professional development opportunities for teachers so that they are able to learn about student cultural backgrounds. These school leaders also need to ensure that teachers are culturally competent enough to develop and initiate appropriate curriculum for minority students (DEMMERT, 2001).

According to Fullan (2002), culturally relevant school leaders must lead change efforts as agents who transform the teaching and learning culture of their schools and communities. It is important to note that these leaders operate within a larger culture, the culture of the school district, which must respond to state and federal mandates and policies. How school leaders respond to these mandates and policies influences students' achievement. Therefore, the role of culturally relevant school leaders is challenging and complex because they have to acquire knowledge, skills, abilities, competencies, and attributes that constitute their cultural competence.

In this regard, school leaders need to reflect on their own leadership practice in order to understand the cultural dynamics that occur in their schools. This is a very daunting standard of excellence, which few school leaders are able to fully embrace because it is related to the value of diversity in schools as well as the preservation of the cultural dignity of students. Finally, culturally relevant leadership enables principals and vice-principals to create an inclusive and instructionally powerful learning environment in their schools. 


\section{Culturally Relevant Pedagogy}

Scholars have developed a theory of culturally relevant pedagogy, which examines teaching and learning processes within a more critical framework by making a more explicit connection between students' home culture and school subject matter (LADSON-BILLINGS, 1995). In this regard, "culturally responsive teaching can be defined as using cultural knowledge, prior experiences, frames of reference, and performance styles of ethnically diverse students to make learning encounters more relevant and effective for them" (GAY, 2000, p. 29). Culturally relevant pedagogies build upon research in educational anthropology that examines cultural congruence between home and school (LADSON-BILLINGS, 1995).

Cultural congruence indicates school respect that both leaders and teachers have for the culture/context of their students. In order for school leaders and teachers to implement principles of cultural congruence, they must have knowledge of and respect for the various cultural backgrounds, traditions, and languages of students found in their school community. These school leaders need to support the development of a rich a base of general sociocultural knowledge about child and adolescent development; second language acquisition; and the ways in which socioeconomic circumstances, language, and culture shape students' school performance in the context of the particular community and school.

Leaders and teachers should be supported in the development of a clear sense of their own ethnic and cultural identities in order to be able to understand and appreciate those of their students. This will help school leaders to understand how their own cultural biases may influence their judgments about students' performance and obstruct students' ability to learn (ZEICHNER, 1996). In a culturally relevant pedagogy approach, teachers need to understand and value the diverse cultures of their students and allow them to explicitly address their understanding of it in the classroom. They also need support and encouragement to teach subject matter in a culturally appropriate manner that is situated within students' funds of knowledge ${ }^{5}$. As well, students need to be educated within an understanding of the historical legacy of racism in society and its current impact upon education (LADSON-BILLINGS, 1995).

\footnotetext{
${ }^{5}$ Funds of knowledge refer "to the historically accumulated and culturally developed bodies of knowledge and skills essential for household or individual functioning and well-being" (MOLL, AMANTI, NEFF; GONZALEZ, 1992, p. 133). According to Rosa (2010), this means that when teachers shed their role as educational professionals and experts as well take on a new role as learners, they come to know their students and their families in new and distinct ways. With this new knowledge, teachers may be able to see that the households of their students contain rich cultural and cognitive resources. These resources can and should be used in classrooms in order to provide culturally responsive and meaningful lessons to tap students' interest and prior knowledge.
} 
The understandings and processes of culturally relevant pedagogy underscore students' connections to their home culture and provide ways for school leaders and teachers to support cultural connections in school and then use them to scaffold students' learning (GAY, 2000). These features of culturally relevant pedagogies assist educators in developing greater specificity in the knowledge needed for school leaders to provide their schools with culturally relevant leadership. A culturally relevant pedagogy is a teaching style that validates and incorporates the cultural background, ethnic history, and current societal interests into teachers' daily instruction of all students. It addresses students' socioemotional needs and uses ethnically and culturally diverse materials for pedagogical action.

As an educational approach, culturally relevant pedagogies empowers students intellectually, socially, and politically by helping them to make use of relevant references to convey knowledge and acquire academic skills with the objective of changing students' attitudes towards academic instruction (LADSON-BILLINGS, 1995). The basic premise of culturally relevant pedagogy is that "teachers should teach using philosophies and methods that respect, value, and use positively the strengths of students' home cultures, contexts, and languages" (SCHEURICH; SKRLA, 2003, p. 48).

This delineates and promotes the achievement for all students because effective teaching and learning take place in an environment that is culturally supported and learner-centered whereby the strengths students bring to school are identified, nurtured, and utilized to promote their achievement (ROSA, 2010). The academic achievement of students who come from minority students with diverse backgrounds improve if school leaders and teachers ensure that classroom instruction is conducted in a manner that is relevant to students' home and the culture of their community (BANKS, 1991).

For example, Moll, Amanti, Neff, and Gonzalez (1992) studied ethnic minority students in Mexican-American communities in Tucson, Arizona as a means to empower and support their academic achievement. They examined the effects of teachers as co-learners, that is, learning their home culture, practicing reciprocal teaching, and in turn connecting to the culture of the students in order to improve their academic achievement.

Further evidence of this phenomenon resulted from the study conducted by Lipka and Adams (2001), which clearly addressed the application of culturally relevant pedagogy. The purpose of their quasi-experimental study was to determine the effectiveness of a culturally based unit of instruction on mathematics that dealt with the learning of perimeter and area by sixth grade students. The outcome measure was a locally constructed achievement test on mathematical concepts of perimeter and area. Their conclusions of the study were in favor of the effectiveness of the culturally relevant based curriculum treatment as implemented in their study. 
In order to promote the academic achievement of students, Rosa (2010) argues that it is necessary to establish and implement culturally relevant pedagogy through the use of connection between culture and curriculum as well as connection between home and school. Furthermore, in order to establish and implement a culturally relevant pedagogy, reforms must occur in the overall organization of the school.

These reforms included the administrative structure and the ways it relates to diversity by adequately using physical space in planning schools and arranging classrooms. Reforms also include school policies, procedures, and practices that influence the delivery of services to students from diverse cultural backgrounds as well as the involvement of the community within the school, including the institutional approach to community involvement in which families and communities are expected to find ways to become involved in the schools.

For example, Kawagley and Barnhardt (1999) conducted a case study in which they examined the school improvement process undertaken at Yupiit School District (YSD), which consisted of three Yupiaq villages in southwest Alaska that joined in 1984 to form the Yupiit Nation in order to run their own schools. In 1992, a district-level leadership team, trained in the Alaska Onward to Excellence school improvement process, called the first community wide meeting to discuss the values and beliefs that should be passed on to the next generation.

The district team then compiled community values and beliefs, drew up a draft mission statement, and listed tentative goals for students (KAWAGLEY; BARNHARDT, 1999). After extensive community feedback, the YSD school board adopted the following students' goals such as knowledge of Yup'ik values, culture, and subsistence skills; preparation for work and further education; respect and positive attitudes toward life, learning, and community; development as lawabiding citizens; and ability to communicate in Yup'ik and English languages.

Local leadership teams then identified the goal of greatest concern in each community and developed specific actions to advance that goal. By the end of the third year of this process, results included improved student attendance, increased parent and elder participation in the school community, provision of curricular training, and closer school-community cooperation. Through this curriculum, everyone in the school community becomes a teacher, every place is a potential classroom, and every activity constitutes a learning opportunity.

In a similar study, Agbo (2002) conducted participatory research at Potsdam, New York with the Mohawk Nation by involving communities in discussion groups to establish the needs for bicultural education for students. Participants discussed the use of Mohawk culture as the arena for curriculum development as well as for the development of Mohawk cultural standards and teacher training in Mohawk culture. It was concluded that learning-teaching environments of Native 
American students must foster self-esteem, reflect increased academic standards, and provide access to cultural resources, particularly at the local community level.

Culturally relevant pedagogies allow teachers to provide and use meaningful learning materials, create classroom environments that include cultures, customs, and traditions that are different from their own, and include lessons that assist students in making meaningful connections between their daily experiences and school-related activities (IRVINE; ARMENTO, 2001). Participating in culturally relevant teaching means that teachers create a bridge between students' home and school lives, while they still meet the expectations of the school district, state, and federal curricular requirements.

The purpose of this instructional pedagogy is to utilize student cultural and linguistic backgrounds, knowledge, and experiences to inform teacher lesson planning, methodology, and pedagogy (ROSA, 2010). Culturally relevant pedagogy provides a way for students to maintain cultural identity while succeeding academically. In other words, it is important for teachers to contextualize instruction and schooling by applying culturally relevant pedagogy in their pedagogical practices as well as by embodying relevance and rigor to the educational process.

Finally, teachers working from a culturally relevant pedagogy perspective demonstrate a belief that students can be competent regardless of race or social class, provide students with scaffolding between what they know and what they do not know, focus on instruction during class rather than busy-work or behavior management, extend students' thinking beyond what they already now, and exhibit in-depth knowledge of students as well as subject matter (LADSON-BILLINGS, 1995).

Culturally relevant pedagogies should focus on the role of mathematics in sociocultural contexts that involve the ideas, procedures, and mathematical practices associated with ethnomathematics for solving problems members of distinct cultural groups face daily (ROSA; OREY, 2013). Mathematical knowledge in the culturally relevant pedagogy may be viewed as an approach of an ethnomathematics program (ROSA, 2010).

\section{Culturally Relevant Pedagogy and Ethnomathematics}

Important changes in mathematical instruction need to take place in order to accommodate continuous and ongoing change in the demographics of students in our classrooms. It is necessary to integrate a culturally relevant pedagogy into the existing mathematics curriculum because it proposes that teachers contextualize learning by relating mathematical content to student real life-experiences (ROSA, 2010). 
The guidelines of both the National Council of Teacher of Mathematics (NCTM, 1991) and the Brazilian Ministry of Education and Culture (BRASIL, 1997) highlight the importance of building connections between mathematics and students' personal lives and cultures. When practical or culturally-based problems are examined in a proper social context, the practical mathematics of social groups is not trivial because it reflects values, perspectives and themes that are linked to the daily lives of students (ROSA; OREY, 2007).

In this perspective, students may be successful in mathematics when their understanding of it "is linked to meaningful cultural referents, and when the instruction assumes that all students are capable of mastering the subject matter" (LADSON-BILLINGS, 1995, p. 141), such as mathematics. In this regard, Rosa (2010) states that curricular activities developed according to the principles of a culturally relevant pedagogy focus on the role of mathematics in a sociocultural context that involves the ideas and concepts associated with an ethnomathematical perspective to solve problems.

In other words, Rosa (2010) states that mathematics knowledge in culturally relevant pedagogies is perceived as versions of ethnomathematics. This happens because ethno is defined as culturally identifiable groups with their jargons, codes, symbols, myths, and even specific ways of reasoning and inferring; mathema is defined as categories of analysis; and tics is defined as methods or techniques for solving problems faced daily. In a culturally relevant mathematics classroom, teachers build from students' previous knowledge (ethno) and direct the lessons toward their culture and experiences (mathema) while developing their critical thinking skills (tics).

The inclusion of deep cultural aspects in the mathematics curriculum have long-term benefits for student mathematical attainment because cultural aspects contribute to recognizing mathematics as part of daily life, enhancing the ability to make meaningful connections, and deepening the understanding of mathematics (ROSA, 2010). The pedagogical work towards an ethnomathematics perspective allows for a broader analysis of the school context in which diverse pedagogical practices transcend the classroom environment because these practices embrace the sociocultural context of the students. In this regard, the pedagogical elements necessary to develop the mathematics curriculum are found in the school community (CHIEUS, 2004; DAMAZIO, 2004).

In this direction, the field of ethnomathematics presents some possibilities for educational initiatives that help to reach this goal because it is a research program that guides educational pedagogical practices (D'AMBROSIO, 1990). However, it is necessary to point out that the incorporation of the objectives of the ethnomathematics program as pedagogical practice in the school curricula and its operationalization and transmission in the field of education is a field of study that is still developing its own identity in the pedagogical arena (ROSA; OREY, 2013). 
The trend towards ethnomathematical approaches to mathematics curriculum and culturally relevant pedagogies reflect a comprehensive development in mathematics education. Ethnomathematical approaches are intended to make school mathematics more relevant and meaningful to students in order to promote the overall quality of education. In so doing, it is necessary to plead for a more culturally relevant view of mathematics to be incorporated into the school curriculum (ROSA; OREY, 2013).

A mathematics curriculum that is based on student context and own knowledge, and which allows teachers to have more freedom and creativity to choose academic mathematical topics to be covered in the lessons (ROSA; OREY, 2013) needs to be encouraged and supported by school leadership. This pedagogical approach can be achieved through dialogue between teachers and students to discuss mathematical themes that help them to reflect about problems that affect society.

In this context, students investigate conceptions, traditions, and mathematical practices developed by the members of distinct cultural groups in order to incorporate them into the mathematics curriculum. Hence, teachers can engage students in the critical analysis of the dominant culture as well as the analysis of their own culture through an ethnomathematical perspective (D’AMBROSIO, 1990).

A culturally relevant mathematics curriculum based on an ethnomathematical perspective infuses the student background in the learning environment in a holistic manner where students are given opportunities to relate to new learning experiences to acknowledge the skills they have previously learned or see in their outside community (ROSA; OREY, 2013).

Culturally relevant pedagogies support the view that "mathematics is conceived as a cultural product which has developed as a result of various activities" (BISHOP, 1988, p. 182). The objective of this approach is to make mathematics more relevant to students because every culture is assumed to have mathematical responses to problems faced daily and these responses are valid content for the development of mathematics lessons.

Teachers using this kind of curriculum would be full of examples that are drawn on the students' own experiences that are found in their sociocultural environment. For example, Rosa and Orey (2013) argue affirm ethnomathematics aims to draw from the students cultural experiences and practices of the individual learners, the communities, and the society at large, in using them as vehicles to not only make mathematics learning more meaningful, but more importantly, to provide students with the insights of mathematical knowledge as embedded in their social and cultural environments. 


\section{An Example of Culturally Relevant Pedagogy in an Ethnomathematical Perspective:} The Mathematization of the Gable

The gable is one of the most popular roof designs due to its attractive symmetrical shape and efficiency at shedding water. A member from a roofing contractor (a cultural group) can easily describe the practices acquired for the construction of a roof gable, which is the most commonly used type of pitched roof construction.

After choosing the type of tile such as red roofing tiles or shingles to begin the construction of the roof, it is necessary that roofing contractors calculate the slopes of the beams that form the triangles in the gable. Gabled roofs often possess a ridge near or at the center and slopes in two directions. It is simple and common in design, economical to construct, and can be used on any type of structure, and in any type of climate.

Triangles are applied in roofing constructions because they are stable, rigid, and have no mobility. The main objective of the roof is to provide protection from climate because they are strong enough to withstand high winds and quickly shed moisture and often snow and ice quickly. Roof slope and rigidness are for shedding water and any excess weight provided by snow and ice and bearing any extra additional weight.

For example, in Brazil, roofing contractors calculate the slope of the roof by applying a ratio between the height and the length of the gable, which is expressed as a percentage. For example, the percentage of the slope (trim) for the roof to the tiles is at least $30 \%$ so that rainwater can quickly drain. According to this approach, for each meter $(100 \mathrm{~cm})$ that runs horizontally, there is a vertical rise of $30 \mathrm{~cm}$ (ROSA; OREY, 2017).

Thus, if the length of the gable is $\mathrm{L}=8$ meters, roofing contractors mentally perform the percentage calculation by using $\mathrm{a}=4$ meters, which is half of that measure. Then, they multiply it by the percentage of the slope of the roof. For example, $30 \%$ of 4 meters corresponds to the height of $1.20 \mathrm{~m}$. Figure 1 shows the scheme of a gable used in roof constructions (ROSA; OREY, 2017).

Figure 1: Scheme of a gable used in many roof constructions in Brazil

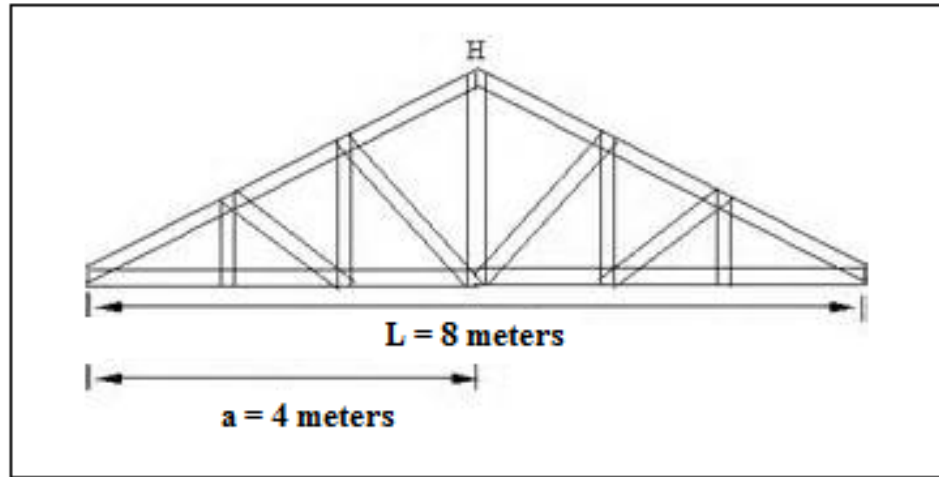

Source: Orey and Rosa (2017, p. 158) 
Conversely, researchers and investigators have described this mathematical practice by applying the Pythagorean Theorem. It is important to state that the basic parts of the gable are the ridge board, gable studs, and common rafters. A gable roof slopes downward in two directions, which is like two right triangles joined together at the vertical line of the triangle.

Figure 2: Pythagorean Theorem and the roof framing

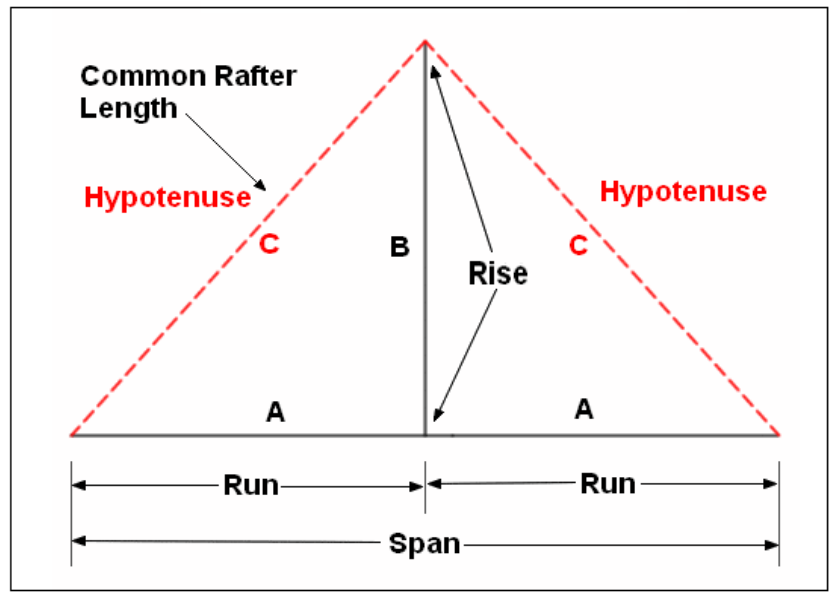

Source: Available in: https://br.pinterest.com/pin/562035228473726793/

This context enables Rosa and Orey (2017) to explain this mathematical practice because the ridge board runs along the peak of the roof parallel to the outside walls. The top of the common rafters are nailed to the ridge board and slope downwards to the outside walls where they are nailed to the ceiling joists and the outside walls. All of the common rafters are the same size and length for each span and roof pitch. For example, the informal calculation of the height (trim, flow) of the gable does not preclude the use of the Pythagorean Theorem by these professionals who strive to compare, interpret, and explain this mathematical knowledge they observe and experience in daily labor activities.

It important to reemphasize how ethnomathematics studies the cultural aspects of mathematics and presents the mathematical concepts of the school curriculum in a way that is related to the students' cultural backgrounds by enhancing their ability to make meaningful connections and deepening their understanding of mathematical content (ROSA; OREY, 2013). This kind of curriculum motivates students to recognize mathematics as part of their everyday life and enhances students' ability to make meaningful mathematical connections by deepening their understanding of all forms of mathematics.

For example, Duarte (2004) investigated the uniqueness of mathematical knowledge produced by workers in the home construction industry through the study of mathematical ideas and practices 
that they develop in the construction sites. In this study, there was a reflection on the mathematical knowledge possessed by the members of this working class to legitimate their knowledge in order to determine the pedagogical and curricular implications that are inferred in the process of production of this knowledge.

The objective of developing an ethnomathematical curriculum model for classrooms is to assist students to become aware of how people mathematize and think mathematically in their culture, to use this awareness to learn about formal mathematics, and to increase their ability to mathematize in any context in the future. This kind of curriculum leads to the development of a sequence of instructional cultural activities that enables students to become aware of potential practices in mathematics in their culture so that they are able to understand the nature, development, and origins of academic mathematics (ROSA; OREY, 2013).

Students also value and appreciate their previous mathematical knowledge, which allows them to understand and experience these cultural activities from a mathematical point of view, thereby, allowing them to make the link between school mathematics and the real world. An ethnomathematical curriculum helps students understand the nature of mathematics because it is an effective tool that contributes to improve the learning of mathematics of minority students (ROSA; OREY, 2007).

The integration of ethnomathematics and culturally relevant pedagogy into the mathematics curriculum focuses on the development of this research area as a process, rather than a collection of facts because it is based on the idea that mathematics is a human creation that emerges as people attempt to understand and comprehend the world around them. Therefore, mathematics can be seen as a process as well as a human activity rather than just a set of academic content to be consumed and forgotten (ROSA, 2010).

The implication of this kind of curriculum is related to the application of relevant contexts in learning and teaching mathematics, but it is also about generating formal mathematics from cultural ideas. Thus formal mathematics is better understood, appreciated, and made more meaningful to its learners.

\section{Final Considerations}

Culturally Relevant Education was developed out of concern for serious academic achievement gaps experienced by many low-income students and from linguistically and culturally diverse environments. It uses the cultural knowledge, prior experiences, frames of reference, and learning styles of ethnically and linguistically diverse students to make learning more relevant and 
effective with the objective to strengthen their connectedness with schools and as consequence reduce behavior problems and enhance learning.

Schools benefit from culturally relevant perspectives by contextualizing instruction and schooling practices while maintaining academic rigor and helping students to achieve their academic potential. In culturally relevant schools, school leaders, teachers, and staff members are enabled to both recognize and build upon the diversity and strengths of students by applying culturally relevant instructional strategies. These professionals identify and remove obstacles that may have been inadvertently placed in the path of students through their prior schooling. They have high expectations for all students and are held accountable to high standards.

Culturally relevant leadership reflects the influence that culture has on the learning process. It is one of the most important roles for contemporary school leaders because it is rooted in culturally relevant education theory, which is grounded in the beliefs that culturally and linguistically diverse students are able to excel in academic endeavors. In order to achieve this goal, it is necessary to implement culturally relevant pedagogy into the school curricula because it helps to develop students' intellectual, social, emotional, and political learning by using their cultural referents to facilitate the acquisition of their knowledge, skills, and attitudes.

Culturally relevant pedagogies provide ways for students to maintain their cultural identity while succeeding academically. They incorporate diverse teaching methodologies designed to fit school culture to cultural backgrounds and to form a firm basis for helping students to understand themselves and their peers, develop and structure social interactions, and conceptualize knowledge. Hence, there is a need to further examination of the embeddedness of mathematics in culture and how it takes on the cultural nature of knowledge production in the mathematics curriculum.

Ethnomathematics studies the cultural aspects of mathematics and presents the mathematical concepts of the school curriculum in a way that is related to student cultural background by enhancing their ability to make meaningful connections and deepening their understanding of mathematics. It links students' diverse ways of knowing and learning and culturally embedded knowledge with academic mathematics because it explores academic and culturally rich ways to provide more inclusive developmental programs for the diverse populations served at educational institutions.

Teaching mathematics through cultural relevance and diverse ethnomathematical perspectives helps students to know about reality, culture, society, environmental issues by providing mathematical content and approaches that enable them to successfully master academic mathematics. Both ethnomathematics and culturally relevant pedagogy-based approaches to mathematics curriculum are intended to make school mathematics relevant and meaningful as well as to promote the overall success of student educational experience. 


\section{References}

AGBO, S. Unstated features of cultural deprivation or discontinuity: culture standards for administrators and teachers of aboriginal students. Journal of Educational Administration and Foundations, v. 16, n. 2, p. 10-36, 2002.

ATKINSON, D. R., MORTEN G.; SUE, D. Counseling American minorities: a cross-cultural perspective. Madison, WI: Brown \& Benchmark, 1993.

BANKS, J. A curriculum for empowerment, action, and change. In: SLEETER, C. E. (Ed.), Empowerment through multicultural education. Albany, NY: SUNY Press, 1991. pp. 125-141.

BEAUBOEUF-LAFONTANT, T. A movement against and beyond boundaries: politically relevant teaching among African American teachers. Teachers College Record, v. 100, p. 702-718, 1999.

BISHOP, A. J. Mathematics enculturation: a cultural perspective on mathematics education. Dordrecht, The Netherlands: Kluwer, 1988.

BRASIL. Parâmetros curriculares nacionais: matemática. Brasília, DF: MEC/SEF, 1998.

BURNS, R., KEYES, M.; KUSIMO, P. Closing achievement gaps by creating culturally responsive schools. Charleston, WV: Edvantia, Inc., 2005.

CHIEUS, G. J. Etnomatemática: reflexões sobre a prática docente. In: RIBEIRO, J. P. M.; DOMITE; M. C. S.; FERREIRA, R. (Eds.), Etnomatemática: papel, valor e significado. São Paulo, SP, Brazil: ZOUK, 2004. pp. 185-202.

D’AMBROSIO, U. Etnomatemática. São Paulo, SP, Brazil: Editora Ática, 1990.

DAMAZIO, A. Especifidades conceituais da matemática da atividade extrativa do carvão. Coleção Introdução à Etnomatemática. Natal. RN, Brazil: UFRN, 2004.

DARLING-HAMMOND, L. Doing what matters most: investing in quality teaching. New York, NY: National Commission on Teaching \& America's Future, 1997.

DAVIS, D. M. Toward democratic education: the importance of culturally responsive leadership in $21^{\text {st }}$ century schools. In: HART, P. S. (Ed.), Race, ethnicity and public education. Boston, MA: The Trotter Review, 2002. pp. 5-16.

DEMMERT, W. J. JR. Improving academic performance among Native American students: a review of the research literature. Charleston, WV: ERIC Clearinghouse on Rural Education and Small Schools, 2001.

DUARTE, C. G. Implicações curriculares a partir de um olhar sobre o mundo da construção civil. In: KNIJNIK, G., WANDERER; F.; OLIVEIRA, C. J. (Eds.), Etnomatemática: currículo e formação de professores. Santa Cruz do Sul, RS, Brazil: EDUNIS, 2004. pp. 195-215. 
FARMER, T. A.; HIGHAM, J. R. Culturally responsive leadership: graduate program egalitarianism. Paper presented at the Annual Meeting of the University Council of Educational Administration in Alexandria, Virginia, 2007.

FULLAN, M. Leading in a culture of change. San Francisco, CA: Jossey-Bass, 2001.

GÁNDARA, P., MAXWELL-JOLLY, J.; RUMBERGER, R. Resources need for English learners: getting down to policy recommendations. Davis, CA: UCDavis, 2008.

GAY, G. Culturally responsive teaching: theory, research, and practice. New York, NY: Teachers College Press, 2000.

HART, L. E. Some directions for research on equity and justice in mathematics education. In: BURTON, L. (Eds.). Which way social justice in mathematics education? International Perspectives on Mathematics Education. Westport, CT: Praeger Publishers, 2003. PP. 25-50.

IRVINE, J. J.; ARMENTO, B. J. Culturally responsive teaching: lesson planning for elementary and middle grades. New York, NY: McGraw-Hill, 2001.

KAWAGLEY, A. O.; BARNHARDT, R. A long journey: Alaska onward to excellence in Yupiit/Tuluksak schools. Fairbanks, AK: University of Alaska, 1999.

KRETOVICS, J.; NUSSEL, E. Transforming urban education. Boston, MA: Allyn \& Bacon, 1994.

KLINGNER, J., ARTILES, A. J.; BARLETTA, L. M. English language learners who struggle with reading: Language acquisition or LD? Journal of Learning Disabilities, 39(2), 108-128, 2006.

KLOTZ, M. B. Culturally competent schools: guidelines for secondary school principals. Principal Leadership, p. 11-14, 2006.

KOMIVES, S. R., LUCAS, N.; MCMAHON, T. R. Exploring leadership: for college students who want to make a difference. San Francisco, CA: Jossey-Bass, 2007.

LADSON-BILLINGS, G. Toward a theory of culturally relevant pedagogy. American Educational Research Journal, v. 32, n. 3, p. 465-491, 1995.

LEE, O. Equity for linguistically and culturally diverse students in science education: a research agenda. Teachers College Record, v. 105, n. 3, p. 465-489, 2003.

LIPKA, J.; ADAMS, B. Improving rural and urban students' mathematical understanding of perimeter and area. Fairbanks, AK: University of Alaska, Fairbanks, 2001.

LITTLE, J. W. Teachers' professional development in a climate of education reform. Education Evaluation and Policy Analysis, v. 15, p. 129-151, 1993.

MADDAHIAN, E. Evaluation of the implementation of culturally relevant and responsive education. Publication No. 218. Los Angeles, CA: L. A. Unified School District, 2004. 
MOLL, L. C., AMANTI, C., NEFF, D.; GONZALEZ, N. Funds of knowledge for teaching: Using a qualitative approach to connect homes and classrooms. Theory Into Practice, v. 31, n. 2, p. 132-141, 1992.

NCTM. Professional standards for teaching mathematics. Reston, VA: National Council of Teachers of Mathematics, 1991.

NORTON, S. Executive leadership for effective administration. New York, NY: Pearson Education Inc., 2005.

PASSOW, A. H. Education in depressed areas. New York, NY: Teachers College Press, 1963.

ROSA, M. A mixed-methods study to understand the perceptions of high school leader about English language learners (ELL): the case of mathematics. Doctorate dissertation. College of Education. Sacramento, CA: California State University, Sacramento, 2010.

ROSA, M.; OREY, D. C. Cultural assertions and challenges towards pedagogical action of an ethnomathematics program. For the Learning of Mathematics, v. 27, n. 1, p. 10-16, 2007.

ROSA, M.; OREY, D. C. Culturally relevant pedagogy as an ethnomathematical approach. Journal of Mathematics and Culture, v. 7. n. 1, p. 74-97, 2013.

ROSA, M.; OREYD, D. C. Ethnomodelling as the mathematization of cultural practices. In: STILLMAN, G. A.;BLUM, W.; KAISER, G. (Eds.). Mathematical modelling and applications: crossing and researching boundaries in mathematics education. Cham, Switzerland: Springer, 2017. Scheurich, J. J.; \& Skrla, L. (2003). Leadership for equity and excellence: creating high-achievement classrooms, schools, and districts. Thousand Oaks, CA: Corwin Press, Inc.

TRUEBA, E. T.; BARTOLOMÉ, L. I. The education of Latino students: Is school reform enough? ERIC Clearinghouse on Urban Education, v. 123, n. 1-10, 1997.

TULKIN, S. R. An analysis of the concept of cultural deprivation. Developmental Psychology, v. 6, n. 2, p. 326-339, 1972.

WIBBEKE, E. S. Global business leadership. Oxford, England: Elsevier, Inc., 2009.

YBARRA, R. Cultural dissonance in basic writing courses. Journal of Basic Writing, v. 20, n. 1, p. 37-52, 2001.

ZEICHNER, K. Educating teachers to close the achievement gap: issues of pedagogy, knowledge, and teacher preparation. In B. Williams (Ed.), Closing the achievement gap: a vision to guide change in beliefs and practice. Alexandria, VA: Association for Supervision and Curriculum Development, 1996. pp. 55-77. 